\title{
外傷性頚部症候群に対する低出力レーザーの 星状神経節近傍照射の経験
}

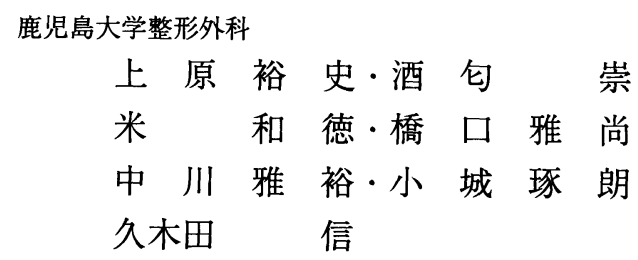

鶴留医院

鶴 留 寿人

\author{
Clinical Effect of Low Power Laser Irradiation \\ around the Stellate Ganglion in Traumatic Cervical Syndrome \\ by \\ Hirofumi Uehara, Takashi Sakou, Kazunori Yone, \\ Masataka Hashiguchi, Masahiro Nakagawa, Takurou Kojou \\ and Makoto Kukita \\ Department of Orthopaedic Surgery, \\ Faculty of Medicine, Kagoshima University \\ Hisato Tsurudome \\ Tsurudome Clinic
} uated.

The clinical effect of low power laser irradiation on the stellate ganglion was eval-

Five males and ten females with traumatic cervical syndrome were irradiated with low power laser. In nine patients, head, neck and upper limb symptoms decreased. Two patients felt warm in their hands and eight patients had decreased pain during the irradiation.

The mechanism of pain relief was thought to be via lowering of tension of the sympathetic nervous system and then increasing tissue flood flow.

The low power laser irradiation around the stellate ganglion was safe and effective for patients with traumatic cervical syndrome.

Key words : Laser (レーザー), Stellate ganglion (星状神経節), Traumatic cervical syndrome（外傷性䅡部症候群）

は じめ に

外傷性䅡部症候群には, 頭・頚部より上肢の疼痛, シビレ,さらには嘔気，めまい等多彩な症状がみられ, 治療に難渋することが多い.これらの症状に対し星状 神経節ブロックが効果があるとされるが, まれに重篤 な合併症を伴うことがある，最近，星状神経節ブロッ
クに代わり低出力半導体レーザーを星状神経節近傍に 照射する試みがなされており, 症状の軽減をみるとの 報告が散見される12).

我々も外傷性顤部症候群に対し, 低出カレーザーの 星状神経節近傍照射を行っており, その臨床的効果に ついて報告する。 


\section{対象および方法}

対象は外傷性頚部症候群の診断にて治療を行ってい る男性 5 例, 女性 10 例の計 15 例で, 年齢は 18 歳か ら 72 歳, 平均 43.0 才である. 受傷より低出力レーザー による治療開始までの䧹病期間は 10 日より 3 年, 平 均 6.4ケ月である.

外傷の内訳は, 交通事故が 14 例, 頭部打撲が 1 例 である。

今回用いた低出カレーザーは波長 $830 \mathrm{~nm}$, 光出力 $60 \mathrm{~mW}$ で, 照射は星状神経節ブロックのポイントであ る, 第 7 䅡椎横突起基部に軽く押しつけるようにして, 主な症状側に対し 10 分間の連続照射を行った。照射 はできるだけ毎日，1日 1 回施行し， 2 週間施行後, 症状の改善を評価した.

症状は自覚症状が主であり, 照射前の程度を 10 点 とし, 治療後の程度を 0 点から 10 点に点数化して評 価した。また照射中の症状の変化とその持続時間を調 べた。

なお各症例とも他の理学療法を併用していた.

\section{結果}

自覚症状の改善をみると, 頭䅡部痛が治療後平均 7 点へ, 上肢痛は平均 6.7 点へ, 上肢のシビレは平均 5.3 点へ，嘔気は平均 8.3 点へ改善していた。 上肢の シビレは比較的よく改善しているが, 嘔気は残存する 傾向がみられた（図 1).しかし，これらの効果は他 の理学療法等の効果も含まれているため, 照射中の効
果をみてみた。

照射中に何らかの効果がみられたものは 9 例 $60 \%$ であった，その内訳は，手指の温感が 2 例（13.3\%） に，頭顏部や上肢の疼痛（シビレ）の軽減が 8 例 (53.3 \%）にみられた.

そしてこれらの効果の持続時間をみてみると温感は 照射中のみが 1 例, 照射後 2,3 分のみの持続が 1 例 であったが, 疼痛の軽隇は照射中のみは 1 例で, 1 時 間から 6 時間が 4 例, 半日より 1 日が 3 例と, 疼痛に 対する効果がやや長く持続する傾向にあった。

\section{考察}

低出力レーザーは 1960 年代に開発され, 慢性疼痛 疾患の治療において, 疼痛軽減の効果が認められ, 最 近はペインクリニックを中心に星状神経節近傍照射に てブロックと同様の効果があると報告されている.

今回用いたレーザー治療器は出力 $60 \mathrm{~mW}$, 波長は 赤血球への吸収が最も少ないとされる $830 \mathrm{~nm}$ のもの である。

低出カレーザーの疼痛軽減の作用機序は, 神経組織 の興奮性を抑制，または過緊張を緩和し，その結果組 織の血流改善を促し，このため疼痛の軽減，または抗 炎症の効果が生じると考えられる（図 2 ）。

またレーザーは長時間の照射にても組織障害が認め られず，副作用の危険性が少なく，毎日施行すること も可能である.

低出カレーザーの利点, 欠点をまとめてみると, 利 点としては組織への障害はないとされており, 副作用,
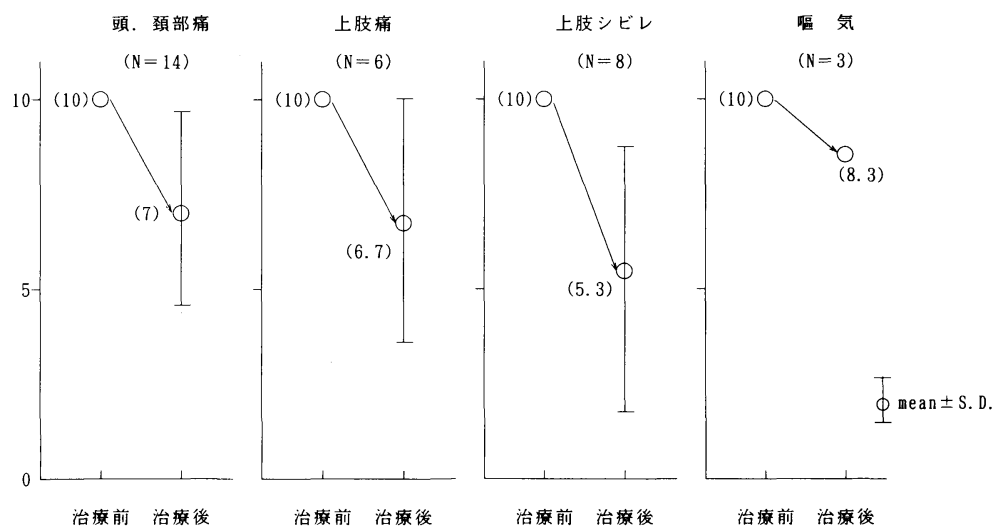

図 1 自覚症状の改善

治療前を 10 点として評価した 


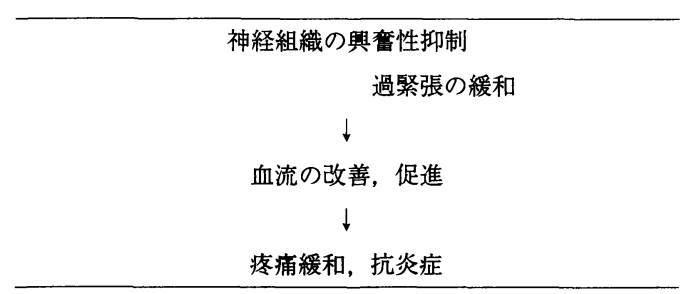

図 2 低出力レーザーの疼痡緩解の作用機序

合併症の可能性が少なく安全ということである．また 治療中の疼痛も少ない. 欠点は効果発現が今回の調査 でも $60 \%$ で, やや不確実といえる．また効果の持続 時間が短い.

一方星状神経節ブロックの欠点としては, 施行時の 疼痛があり，さらには，稀ではあるが重篤な合併症が みられることである。

以上, レーザー治療器を用いた星状神経節近傍への
照射は，正確な手技を必要とするが，その安全性を考 えると外傷性頝部症候群に対し，有用な治療法である と考えられた。

$$
\text { ま と め }
$$

(1)外傷性䅡部症候群に対する低出カレーザーの星状 神経節近傍照射で $60 \%$ に効果が認められた.

(2)レーザー治療器は安全性が高く, 外傷性䅡部症候 群に対する治療法として有用であると考えられた。

\section{参 考 文 献}

1）加藤麦夫他 : 低出力 $\mathrm{He}-\mathrm{Ne}$ レーザーによる星状神経節 照射について. 日口外誌, $33: 2347-2357,1987$.

2）吉沢明孝他 : 低出カレーザーによる星状神経節近傍へ の照射効果について. 日本レーザー医学会雑誌, $13: 3-7$, 1992. 